\title{
Halal entrepreneurship from Maqasid-al-Sharia'h perspective: inseparable concept for Halalpreneurs
}

\author{
Abdullah, M.A. and Azam, M.S.E. \\ International Institute for Halal Research and Training (INHART), International Islamic University \\ Malaysia (IIUM), 53000 Gombak, Malaysia
}

Article history:

Received: 8 August 2019

Received in revised form: 26

October 2019

Accepted: 15 December

2019

Available Online: 10

February 2020

\section{Keywords:}

Halal,

Entrepreneurship,

Maqasid-al-Shariah,

Halalpreneur,

Halalpreneurship

DOI:

https://doi.org/10.26656/fr.2017.4(S1).S07

\begin{abstract}
Entrepreneurship has become one of the vital activities for economic development. It is synonymous with job creation, innovation, improvement in the societal well-being and economic growth in developed and developing countries alike. There is great interest in entrepreneurship globally as well as in Malaysia. Over the past few years, many individuals, as well as families, are actively engaged with the small business. Also, in light of the 2013 GEM study, $12.7 \%$ of Americans are effectively occupied with beginning a business or are the proprietor/director of a business that is under three years of age. Simultaneously, the Halal industry, that represents the global Islamic economy, is the fastest-growing market in the world with $\$ 2.3$ trillion market value. Halal entrepreneurs (Halalpreneurs) are the major contributors to this achievement as they constitute a significant portion of the total establishment in most of the Muslim countries. That is the reason Entrepreneurship has turned into a conventional term that depicts a wide range of practices that include being innovative, devilish and tricky. Entrepreneurship has been defined by many scholars, researchers, industry players, and academicians globally which have also been perceived in the same way by most of the economies around the world. However, the Islamic economy looks at the concept of 'entrepreneurship' in a different way and perceives it as 'Halalpreneurship'. To define entrepreneurship in the halal industry, although, the term 'Halalpreneurship' is being used, surprisingly the term has not been defined properly yet. It is essential for the Muslim entrepreneurs to have a proper understanding of Halalpreneurship from Maqasid-al-Shariah perspective. Such point of view is crucial to justify the term in the Halal industry and differentiate from conventional entrepreneurs. On this context, this paper provides concept and definition of Halalpreneurship justifying from the perspective of Maqasid-al-Sharia'h. It also identifies the differences between Halalpreneurs and entrepreneurs using secondary resources available in the forms of literature, research papers, journal papers, articles, conference papers, online publications, etc. The findings of the study will clarify the concept of Halalpreneurship from Maqasid-al-Sharia'h perspective and recognize Halalpreneurs distinguished from conventional entrepreneurs.
\end{abstract}

\section{Introduction}

Islam bases its communities on principles that distinguish it from other systems. Islam integrates construction and laying the sound foundations: contractual, economic, political and social. All of them are a coherent and cohesive structure that helps the community to achieve the best results. The Qur'an not only permits but encourages business, trading, and entrepreneurship. For Muslims, business and entrepreneurship are considered to be the high esteem as it was also the profession of the Prophet (PBUH) (Solaiman and Yasmin, 2012). Entrepreneurship has been defined by many scholars, researchers, and organizations because of its significant contribution to the economy and society. Simultaneously, it has been explained from a different perspective by different researchers to integrate high standards of ethics because of some big financial scandals, recently (Oukil, 2013). Interestingly, Emami and Nazari (2012) argued that entrepreneurs who have higher faith and commitment to their religion are more ethical in their business conduct. However, all these ethical guidelines and business conduct behavior in entrepreneurship have been revealed in Islam 1400 years back through the Prophet (PBUH). All it requires is to do some critical investigation and analysis of the different source of 
Islamic law. Every business activity for any economy are based on three concepts in Islam, namely livelihood (alrizq), permissible (Halal), and prohibited (Haram) which are also founded by the five objectives of Maqasid-alShariah (Faizal et al., 2013). Global halal industry, which also represents the global Islamic economy, has been identified as the fastest-growing market in the global economy as the consumers around the world are becoming aware of the concept 'halal' which is not anymore confined to food only (Thomson Reuters, 2018). The industry is growing at $20 \%$ per year estimating a value of US\$560 billion (Elasrag, 2016). As of 2017, the total estimated value of the global halal market was US\$4.54 trillion and expected to reach US $\$ 9.71$ trillion by 2025 (Thomson Reuters, 2018). The joining of moral qualities alongside religious qualities opens up the limit of the halal industry from 2.8 billion Muslim shoppers to non-Muslim customer also around the globe.

Therefore, it is the essence of time for all entrepreneurs, especially Muslim entrepreneurs, to know the concept of Halalpreneurship and looking into it through Maqasid-al-Shariah perspective. Such point of view of Halalpreneurship explains how Halalpreneurs differ from conventional entrepreneur, what, how and for whom to produce in the economy, who are the stakeholders, what are the motivations, and what is the scope of knowledge in Halalpreneurship? On this regard, the aim of this paper is to investigate the history of entrepreneurship in Islam and clarifies the concept and definition of Halalpreneurship. Another objective is to justify Halalpreneurship through Maqasid-al-Shariah perspective as an inseparable concept for Halalpreneurs. Simultaneously, it tries to differentiate Halalpreneurs from conventional entrepreneurs by examining the different aspects of entrepreneurship from Maqasid-alShariah view. This paper fulfills the urgent demand of the global Halal industry, as stated in the report Thomson Reuters (2018), clarifying the concept and definition of Halalpreneurship which will help the business ventures in the Halal industry differentiate themselves from conventional entrepreneurs. This perspective will motivate them to subscribe for more halal business and contribute to the Islamic economy. It can also be useful for policymakers providing effective and suitable policies to develop training programs on Halalpreneurship, halal marketing and other areas of Halal industry.

\section{Methodology}

To achieve the objectives of this paper, content analysis was adopted. The content analysis comprised of an extensive literature review from previous studies that comprised of a research paper, thesis, journal articles, books, explanation of Al-Quran and Hadith, online articles, and secondary data from different statistical website and research papers.

Adopting the methodology, as mentioned above, the following sections of the paper start with reviewing the literature on the definition of entrepreneurship and Halalpreneurship followed by the review of Halalpreneurship from Maqasid-al-Shariah perspective. Additionally, before drawing the conclusion, the paper discusses the differences between Halalpreneurs and entrepreneurs by reviewing literature from different aspects.

\section{Review on definition}

To achieve the objectives of the study this part of this paper reviews the works of literature to provide a comprehensive definition of Halalpreneurship or halal entrepreneurship. It starts with reviewing the conventional definition of entrepreneurship in brief followed by reviewing the definition of Halalpreneurship.

\subsection{Entrepreneurship}

Entrepreneurship stems from the originates from the French word entreprendre signifying 'to embrace or to take in one's very own hands. Business enterprise can be depicted as a procedure of activity a business person attempts to build up his venture. It is a creative activity that is based on the ability to create and establish something from nearly nothing. Entrepreneurs are risktakers who react to opportunities, bear uncertainty and balance the supply and demand in the specific market (Kuratko, 2016). As per Peter Drucker, Entrepreneurship is characterized as 'a methodical advancement, which comprises in the deliberate and sorted outlook for changes, and it is the orderly examination of the open doors such changes may offer for financial and social development.' The field of entrepreneurship is likewise characterized by Shane and Venkataraman (2000) as the investigation of chances to make future item and administrations including the methodology, the general population in control and what is being delivered. Rindova et al. (2009) have characterized business entrepreneurship as the endeavors to achieve novel cultural, social, monetary and institutional conditions through the activities of an individual or gathering of individuals. Low and MacMillan (1988), Gartner, (1988) and Lumpkin and Dess, (1996) defined entrepreneurship as the creation of new enterprises or organizations. Entrepreneurship may also mean taking advantage of opportunities by novel combinations of resources in ways which affect the marketplace. This is regardless of 
the resources that the entrepreneurs are controlling.

The word 'entrepreneur' immediately conjures up images of business icons like Steve Jobs or Bill Gates. While these rich, famous and successful individuals can be inspirational for some, most of us would find it difficult to associate our own lives, personalities or abilities with them. Business Dictionary characterizes enterprise as the limit and eagerness to create, compose and deal with a business adventure alongside any of its dangers so as to make a benefit. In Investopedia, an entrepreneur is a person who, as opposed to filling in as a worker, establishes and maintains a private company, expecting every one of the dangers and prizes of the endeavor. The business entrepreneurship is normally observed as a trend-setter, a wellspring of new thoughts, products, administrations, and business/or methods. Also, in financial matters, business enterprise joined with the land, work, regular assets, and capital can deliver a benefit (Schaper et al., 2011).

It has been realized from the above reviews of entrepreneurship that the definition is more or less similar. The conventional entrepreneurs are more focused on market demand and supply while taking risk and uncertainty (Kuratko, 2016). They intend to make social development deliberately without considering the specific need and specific target consumer i.e. focused on making a profit (definition of Peter Drucker, and Shane and Venkataraman). Additionally, entrepreneurs are to take the advantages of available resources only while affecting the market in case of scarcity of the resources (Lumpkin and Gartner definition). Moreover, scholars have tried to make ethical integration to the definition for entrepreneurs to become honest, socially responsible, and not to focus making profit only by any means (Emami, 2012; Oukil, 2013). Therefore, the following look into the definition of Halalpreneurship to see the differences from the conventional one.

\subsection{Halalpreneurship}

Halalpreneurship is holistic in Islam entails entrepreneurship as an element that is not separated from Islam. Halalpreneurship is the entrepreneurship that is within Shari'ah's scope (Aqidah, Fiqh, Akhlaq) so that its activities are not alienated from obligations in Islam. Halalpreneurship includes the role of the human being as a Khalifah (Caliph) in the world, to develop and prosper the world; means the activities of entrepreneurship should contribute to the good and prosperity of society, Ummah and humanity.

Halalpreneurship is a recently created idea that joins halal advancement to business exercises that are executed as halalpreneurial activities. It includes the majority of the capacities, exercises, and activities related to the view of chances and formation of associations to seek after them. The halal innovative procedure is a complex phenomenon; be that as it may, this procedure is significant in comprehension halalpreneurial development.

Halalpreneurship is an essential part of the Islamic religion. Moreover, it is considered as jihad fi sabilillah (done in earnest in order to uphold thi teachings of Islam and elevate its symbol), to be a source of livelihood to the community (produce goods, provide services, create jobs, eradicate poverty, eradicate social, criminal and all wrongdoing. On top of that, worship and righteous deeds are deeds to bridge the relationship between mankind and Allah Subhanahu Wa Taala (SWT) (Kedah et al., 2015)

Imam Al-Ghazali has written in his Ihya Ulum alDin:

It is compulsory upon every Muslim who is involved with it (business and trading), to study the laws of buying and selling because the seeking of knowledge is a duty upon every Muslim. When we say the seeking knowledge is such a duty, we also mean knowledge of all those affairs of trade and business. Those in service and employment should know the laws applying to them and those who work for a living should know the laws (as related to them), no matter what occupation he is in. In such a way, they will become aware of the things which cause their acts to be illegal according to the shari'a; and they will be able to avoid these acts. When there are some rare or uncommon cases or instances which one does not know whether is halal or haram, one should not act upon it until such time he has the opportunity to inquire the matter from the learned scholars (of Islam).

From the above quotation it is very clear about the ethical and moral responsibilities prescribed in Islam for any Muslim entrepreneur (Halalpreneur). Moreover, it is the consensus of the Muslim scholars that is not permissible for a Muslim person to start an affair until he or she identifies what Allah has obtained in the matter. This is also applicable for those who would like to be engaged in business and trading, or accept an offer from an employer, which to make a loan or invest. Halal earnings bring the love of Allah SWT, enlightenment, knowledge, righteous thoughts, courage and attentiveness. A Halalpreneur is supposed to take care of these matters in his/her Halalpreneurship.

Additionally, Halalpreneurship also avoids any matter which is haram (not permissible) in Islam. Halalpreneurs perceive the haram (prohibited) earnings as irreligiousness, bring overwhelmed by one's own 
desire, the absence of courage and destruction of one's faith in Allah SWT. It is mentioned in Al-Quran-

"O you who have believed, fear Allah and give up what remains [due to you] of interest if you should be believers". (Al-Qur'an, 2: 278)

From the above reviewed works of literature, references from Quran and Hadith, and quotation of Islamic scholars, the concept of Halalpreneurship is well defined and understood, which was the first objective of this study. The following section looks into this concept of Halalpreneurship from maqasid-al-Shariah perspective.

\section{Review of Halalpreneurship from Maqasid-al- Shariah perspective}

As section-3 provides the definition and a clear concept of Halalpreneurship, this section of the paper tries to look Halalpreneurship from the perspective of Maqasid al Shariah. Firstly, it reviews on Maqasid al Shariah and its objectives. Secondly, a short review of Halal and Haram is done. And finally, the definition of Halalpreneurs is provided based on the literature and interpretations.

\subsection{Maqasid-al-Shariah}

Halalpreneurship is the profession of earning a livelihood, living life on earth, and serving the whole ummah while representing oneself as a good Muslim. On this regard, Halalpreneurs must know the rulings of Islam and the objectives of these rulings. The Arabic word Maqasid [singular maqsid] implies the meaning of objectives or purposes and when it refers to Shari'ah [Maqasid Al Shari'ah] it specifically means the goals and purposes of Shari'ah (ibn Ashur, 2006).

Most Muslim researchers are of the assessment that a definitive goal [Maqasid Shari'ah] which are a need [daruriyyah] for humankind to have the option to live calmly in this world, as per al-Quran and al-Sunnah, incorporate five fundamental zones:

1. Protection of Religion-the leader must be able to pay attention to all the needs and financial support for all religion, not only Islam, and provide and protect their rights to practice their ritual. This is applied to develop a Muslim-friendly ecosystem.

2. Protection of Life- In Islam, homicide is not permitted. The same applied to not consume or produce harmful products and goods.

"And do not kill the soul which Allah has forbidden, except by right. And whoever is killed unjustly - We have given his heir authority but let him not exceed limits in [the matter of] taking life. Indeed, he has been supported [by the law]". (Al-Qur'an, 17: 33)

3. Protection of Lineage or Offspring- Islam strongly recommend people to get married. It also prohibits any sexual relationship before marriage. This applies during traveling where Muslim-friendly tourism comes into action.

4. Protection of Intellect or Faculty of Reason, and, lastly- Any material that might damage the brain and intellectual ability is totally prohibited in Islam, like intoxicant and alcohol. The same applies to produce and trading with them.

5. Protection of Material Wealth or Property- Islam liberates people to seek their wealth in a positive manner. Therefore, there are few unjust transactions that have been prohibited in Islam such as usury (riba). Also, there is exacting discipline for the individuals who take somebody's property.

"Allah destroys interest and gives increase for charities. And Allah does not like every sinning disbeliever". (Al-Qur'an, 2: 276)

Besides having a clear understanding and knowledge of Maqasid Shari'ah, Halalpreneurs should also know about what is permissible (halal) and what is not permissible (haram) while conducting their businesses.

\subsection{Halal and haram}

Halal-or in some contexts 'Halalan'- is an Arabic word which means "permissible", "legal" or "allowed". Prescribed as a guideline for Muslims to observe in their daily practice, the concept of halal or permissibility includes all aspects of justice and equality for all, including acceptability by non-Muslims.

Tayyib-or in some contexts 'Tayyiban'- means good, wholesome or safe. Muslims are obliged to consume safe and non-harmful goods.

"O you who have believed, do not prohibit the good things which Allah has made lawful to you and do not transgress. Indeed, Allah does not like transgressors (87). And eat of what Allah has provided for you [which is] lawful and good. And fear Allah, in whom you are believers (88)." (Al-Qur'an, 5: 87-88)

Haram is the antonym to Halal. The word haram means 'prohibited' and 'unlawful'. In business conduct, any activity that includes Haram foods or ingredients is prohibited to every Muslim including that product or service. While deciding on halal and haram for anything there are certain principles in Islam. For example, Natural permissibility of things created by GOD (Allah SWT), unless explicitly forbidden; The decision of halal and haram is the right of Allah SWT (Al-Qur'an, 5: 87- 
88); What is halal is enough and what is haram is redundant; Islam does not limit the Muslim's options, instead it makes wider choices and alternatives. For instance, Allah SWT prohibits riba (usury) but encourages the profitable trade; Falsely representing haram as halal is prohibited (Sahih al-Bukhari, 5590); Good intention does not make the haram acceptable (Sunan Abi Dawud, 59); Doubtful (shubhah) should be avoided as mentioned in the Hadith (Jami` at-Tirmidhi, 1205) that is highlighted earlier in this section; Compelling necessity (darurah) dictates exception; Islam is not unmindful to the necessities of life, to their magnitude, nor to human weakness and capacity to face them. Therefore, on the occasion of necessity, the prohibition is removed to suit the situation (Al-Qur'an, 2: 173).

Now, that the objectives of Maqasid Shari'ah, as well as halal and haram, have been explained, entrepreneurs can be defined as Halalpreneurs while fulfilling the Shariah requirements and other Halal standards, which are also set in line with Shariah, for respective countries.

\subsection{Halalpreneurs}

Based on the reviewed works of literature and analogy of different references from Quran and Hadith as mentioned earlier sections of this paper, it can be asserted that any Muslim entrepreneur who produces goods and services that follow and comply with Maqasid -al-Shari'ah is known as Halalpreneurs. However, NonMuslim entrepreneurs are allowed to be Halalpreneurs by Islamic scholars based on maslahah 'Public Interest' for the benefit of Ummah and mankind, if they comply with the Sahri'ah laws in the products and services provided.

Halalpreneurs are 'khalifah' and have the responsibilities to develop prosperity and see business as part of 'ibadah' or good deed through the fulfillment of fardhu kifayah (communal obligation). While the Western business person is driven towards enterprise for the most part independent from anyone else intrigue and the longing for individual benefit, the Muslim business visionary begins a business with the expectation of satisfying The Almighty Allah SWT (Kedah et al., 2015).

In other words, a Halalpreneur regards his or her activities as ibadah in the frame of earning a halal living, as declared in Surah Al-Juma'ah:

O you who have believed, when [the adhan] is called for the prayer on the day of Jumu'ah [Friday], then proceed to the remembrance of Allah and leave trade. That is better for you if you only knew (9). And when the prayer has been concluded, disperse within the land and seek from the bounty of Allah, and remember Allah often that you may succeed (10). (Al-Qur'an, 62: 9-10)

This encourages Muslims to be engaged in business and trading while not neglecting the ibadah. Hence, the guiding principles of Halalpreneurs are from the AlQuran and Hadith that are in coordination with the five objectives of Maqasid-al-Shari'ah. The first objective of Protecting the Religion can be addressed by coming up with ideas, products, and services that facilitate the practice of religion, calling to it, teaching it, providing freedom of religion and other incentives for proper spiritual development (Kayed and Hassan, 2011).

Halalpreneurs aims to achieve the second objective by enhancing human life, protecting it, avoiding harmful or toxic products. Simultaneously, Protection of Lineage or Offspring can be addressed by encouraging marriage, forbidding haram relationships, selecting a healthy family to minimize dangerous diseases, healthy upbringing. Halalpreneurs can also play a significant role in the development of education, the prohibition of intoxicant and alcohols that might damage the brain and intellectual ability. Finally, Protection of Material Wealth or Property- To be preserved and enriched through opening alternative sustainable ways for its generation, utilization, distribution and growth on one hand and also blocking means that hinder its generation, circulation, consumption, and growth. The entrepreneur focuses on the profit and the county law in the practice of their business. The five pillars are not propriety, nor in the description of the scope. While on the other hand, Halalpreneurs must fulfill these pillars first for their products or services to be halal.

The concept of and definition of both Halalpreneurship and Halalpreneur have been explained till this point of this paper. Moreover, a close observation of the concept Halalpreneur was also made from the perspective of Maqasid-al-Sharia'h. The following section provides more understanding of Halalpreneurship by identifying the differences from conventional entrepreneurs and stating the characteristics of Halalpreneurs.

\section{Halalpreneurs VS entrepreneurs}

The holistic characteristics and objectives of Halalpreneurs make them unique and different from entrepreneurs. With the differentiated motives and aims, Halalpreneurs are expected to manage their venture successfully and demonstrate a better performance regarding trust and belief towards Islam (Hamid and Sa'ari, 2011). Halalpreneurs can be deviated raising a number of questions; such as, what to produce, how to 
produce, for whom to produce, what are the motivations, and what are the personal characteristics of Halalpreneurs?

\subsection{What to produce}

Entrepreneurs offer and produce what people want and make profits, while on the other hand, Halalpreneurs produce what is permissible (halal) by Shari'ah and is needed by humanity. Goods and services are based on product priorities such as necessities, comfort, luxury, not harmful and non-haram. In other words, Halalpreneurs produce what complies with Maqasid-alShari'ah priorities and classifications:

Daruriyyat (essentials): Required and considered as essential for the establishing of prosperity in this world and the Hereafter.

Hajiyyat (needs): Serve as complementary to the essentials. Without the needs, people will face hardship. Nonetheless, non-presence of the requirements won't make total disturbance of the typical request of life.

Tahsiniyyat (embellishments): Relate to matters which bestow enhancement in the society and guide to an improved life.

Mubahat (Luxury): It is not prohibited but not a basic need cannot be own by everyone

Haram (prohibited): It is not allowed and should not be produced nor consumed.

For instance, a halalpreneur cannot be selling wine and anyone who does is deported from the mercy of Allah SWT.

\subsection{How to produce}

Entrepreneurs seek efficiency and productivity in their production line. They desire maximized profits and any cost and using any approach. On the other side, we see the awakened soul in the Halalpreneurs, as they do not approach the haram product nor the process to make it. They, however, can naturally aim to maximize their profit. In other words, the process of production and generating the income and the profit must be halal. This is where we can distinguish the two categories. This is certainly by complying to Halalan Tayyiban Concept and Standards. For instance:

The item does not contain any parts or results of creatures that are non-halal to Muslims or results of creatures which are not butchered by Shari'ah.

During its planning, handling, bundling, stockpiling or transportation, the item is physically isolated from whatever another item that does not meet the prerequisites of Shari'ah.
Halalpreneurs decide how to produce efficiently keeping in view their profit and motive. Resources are plentiful. If the resources are scarcity, it is either illadvised utilization of assets, unequal dissemination of assets, or absence of learning.

That is why Halalpreneur should have the proper knowledge in both Shari'ah and business to be able to operate efficiently. The Prophet (PBUH) said,

"A time will come when one will not care how one gains one's money, legally or illegally." (Sahih alBukhari 2067)

\subsection{For whom to produce}

The target customer or serving consumer for Halalpreneurs is an important aspect to differentiate from entrepreneurs. Entrepreneurs offer their services and products based on the market's demand. There is no particular group to be served as long as the profit is obtained in the process. Halalpreneurs on the other hand, have the view of production to fulfill human needs to discover new horizons and uncover new opportunities for the benefit of humankind. A Halalpreneur realizes that his or her prime duty and responsibility is to distinguish between what is halal and what is haram as determined by Shari'ah. Only halal good, therefore, can be produced. By complying Maqasid-al-Shari'ah priorities, everyone in the society is provided with basic needs by the state, and Halalpreneurs shall provide goods and services according to product priorities such as necessities, comfort, and luxury. However, as innovative and creative individuals, Halalpreneurs should not focus on luxury goods and services before covering the needs of Muslim Ummah and Humanity.

In 1955, Ray Kroc established the McDonald's ${ }^{\circledR}$ Corporation and opened the primary café in Des Plaines, Illinois. Today, there are more than 33,000 McDonald's ${ }^{\circledR}$ cafés in 119 nations. Beam Kroc kicked the bucket in 1984 yet his heritage is particularly alive. His example of overcoming adversity proceeds with McDonald's ${ }^{\circledR}$ groups of workers, franchisees, and suppliers. His responsibility, devotion, and accomplishments keep on living on at McDonald's ${ }^{\circledR}$ cafés over the world. In 1995, McDonald's $\mathrm{B}$ is the primary Quick Service Restaurant in Malaysia to get the Halal Certification from JAKIM. And in 2016, Saudi Arabia's Lionhorn Pte Ltd becomes the owner of McDonald's ${ }^{\circledR}$ Malaysia through the McDonald's ${ }^{\circledR}$ Developmental Licensee franchising structure. Although the owner was non-Muslim, the restaurant chain is Halal-certified and is a good example of Halalpreneurship, providing food for all levels in society. 


\subsection{What are the motivations}

The conventional entrepreneur is seeking profit before everything else. Though profit maximizing is not forbidden in Islam, profit is not the main motive of Halalpreneurs. Halalpreneurs should look for God's favor over every other factor. A Halalpreneur performs business isn't exclusively for the benefit, yet most importantly, to satisfy the 'fardhu kifayah'. Subsequently, Halalpreneurs ought to vary from different business people in their thought processes and points. It is trusted that on the off chance that they can deal with their business effectively, they ought to likewise have great execution as far as confidence and conviction towards Allah SWT, as they are aiming for al-Falah in the hereafter (Soltanian et al., 2016). Business in Islam is exceptionally respected, and Islam gives the motivators as well as the helpful system for financial and enterprise advancement in the light of the elucidation of the Qur'anic refrain and on the numerous customs of the Prophet Muhammad (PBUH). Allah SWT says:

"And We have made for you therein means of living and [for] those for whom you are not providers." (AlQur'an, 15:20)

\subsection{Who are the stakeholders}

In the conventional entrepreneurship, stakeholders include the supply chain: owners, suppliers, manufacturers, workers, financiers, customers, community and the whole nation affected. Islam looks at the ownership differently from either capitalism or socialism. For instance, in capitalism, there is unrestricted private ownership of property that leads to monopolies. While socialism has no private ownership at all.

From the perspective of Maqasid-al-Shari'ah, Islam protects the right of property without interference with the good of community 'maslahah' and while the property is achieved in a halal way. Having said that, the concept of stakeholders in Islam recognized that everything belongs to Allah SWT and He distributed the wealth and prosperity among His creatures with wisdom and reasoning that we, human, do not understand. And as khalifah, we are entrusted to manage and develop the resources that Allah SWT has created and offered according to the Maqasid-al-Shari'ah. In this context, stakeholders in Halalpreneurship are the same as the conventional one, with the focus of all holders being under the umbrella of the provision of Allah SWT. Therefore, Halalpreneurs here is fulfilling the 'fardhu kifayah' by serving the ummah and humanity and provide extra attention to all details of the supply chain from manufacturing to the end products with the Ihsan.

\subsection{Characteristics of Halalpreneurs}

A number of religious, moral and ethical characteristics, that are developed from the Islamic values, significantly distinguishes Halalpreneurs from entrepreneurs. Firstly, Takwa is the most important attribute of Halalpreneurs that lead them towards success making lots of profits through their business activities. In line with this faith, Halal becomes the first priority for Halalpreneurs. As Allah recommends consuming Halal (Al Quran 5:88) as well as earn Halal (Al-Quran 2:168). Halalpreneurs are also expected to behave responsibly both for consumption and expense as business activities are influenced by the prescription of not wasting by Allah (Al-Quran 7:31). Another characteristic of Halalpreneurs was mentioned by Faizal et al. (2013) in his study is to prioritize worship to Allah SWT which was also identified Sadeq (1977) on the basis of Quranic verses where entrepreneurship (worldly affairs) is encouraged but after praying (Al-Quran 62:10, 15:67). While prioritizing worship to Allah SWT Halalpreneurs become trustworthy in terms of both social and their business conduct. Thus, trustworthy is another characteristic of Halalpreneurs which has been mentioned by the Prophet (PBUH) himself. The Prophet (PBUH) encouraged truthful and trustworthy merchant to be with him together with martyrs on the day of Judgement (Al-Tirmidhi, 14: 1213).

Halalpreneurs are also philanthropists. They contribute to social welfare by providing Zakat, which is one of the five obligations for all Muslims. Being concern about social welfare through charity activities and providing Zakat has been stated in many places in Quran (Al-Quran 2:3, 43, 83, 177, 7:156, 19:31, 19:55, $21: 73,22: 35,41,78,23: 4,27: 3,30: 39,31: 4,41: 7$ and more). Therefore, Halalpreneurs are expected to consider themselves in the position of an Islamic business organization and fulfill their philanthropic responsibility as prescribed in Sharia'h.

Last but not the least, an additional requirement is the knowledge of Islam and Shari'ah concept, halalan tayyiban concept and the categories of Maqasid-alShari'ah for an individual be a Halalpreneur. In other words, a halalpreneur is not necessary a Muslim, as nonMuslims could be Halalpreneurs if they possess the required knowledge. For instance, the halal concept should be implemented in the procurement process, production, packaging, storage, logistics, and others. In this manner, halal learning is crucial to be one of the criteria for Halalpreneurs. Non-Muslim Halalpreneurs is allowed under the condition of public interest 'Maslahah'. Maslahah is an Arabic expression that, in law and social morals, signifies "the basic social great or 
welfare." Maslahah in contrast to its antonym, mafsadah, which means "that which causes or constitutes harm." As indicated by authentic and legitimate writings, it was the second caliph, 'Umar ibn al-Khattab (r. 634-644), who connected the standard of seeking after open approaches that add to the benefit of everyone over those that don't. Imam al-Ghazali and other medieval scholars held that, while the general welfare of Muslims regarding requirements and enhancements ought to be connected to shari'ah through lawful thinking, what was esteemed in setting to be important to the welfare of the network required no other support for usage (Kamaluddin et al., 2005).

\section{Conclusion}

Entrepreneurship is the vital component of any economy has been defined by many scholars and institutions. Some of the characteristics of an entrepreneur have been identified in this study are risktaker, innovator, opportunity seeker, an agent to economic, social, and cultural changes. However, in Islamic economy entrepreneurship has been viewed from the perspective of Maqasid-al-Shariah. Integrating the five principles of Maqasid-al-shariah into entrepreneurship defines Halalpreneurship and reveals the characteristics of Halalpreneurs. Halalpreneurs are khalifah and are responsible to develop the world where Maqasid-al-Shariah is the umbrella of all Halalpreneurs. Halal products and services are the prime goals for being Halalpreneurs aiming to please Allah $S W T$ before any profits. In business production, Halalpreneurs are unique and differ from conventional entrepreneurs in terms of what to produce, how to produce, and for whom to produce. Unlike entrepreneurs, the motivation that works for someone to become Halalpreneur is to have the blessings of Allah SWT which will bring reward both in this world and the world hereafter. Moreover, Halalpreneurs possess the characteristics of Takwa, trustworthiness, prioritizing Halal products and services and worship to Allah SWT, philanthropic responsibility, and knowledge of both business and shariah. Entrepreneurship that does not comply with Shari'ah is not Halalpreneurship. Therefore, Halalpreneurs are different from conventional entrepreneurs regarding their purpose, and intention of business, and the religious, moral, and ethical characteristics they possess. In conclusion, Maqasid-al-Shariah is the ruling of every conduct of human life based on the Quran and Hadith as primary sources. Thus, this becomes an inseparable concept for entrepreneurs to be justified as Halalpreneurs. An extensive discussion and review on Maqasid-al-Shariah were beyond the scope of the paper which has, however, already been detailed out by a number of previous studies. Future study may enhance the concept 'Halalpreneurs' itself with detail deliberation.

\section{References}

Emami, M. and Nazari, K. (2012). Entrepreneurship, religion, and business ethics. Australian Journal of Business and Management Research, 1(11), 59-69.

Faizal, P.R.M., Ridhwan, A.A.M. and Kalsom, A.W. (2013). The entrepreneurs characteristic from alQuran and al-Hadis. International Journal of Trade, Economics and Finance, 4(4), 191. https:// doi.org/10.7763/IJTEF.2013.V4.284

Gartner, W.B. (1988). "Who is an entrepreneur?" is the wrong question. American Journal of Small Business, 12(4), 11-32.

Hamid, S.A. and Sa'ari, C.Z. (2011). Reconstructing entrepreneur's development based on al-Qur'an and al-Hadith. International Journal of Business and Social Science, 2(19).

Ibn Ashur, M. al-T. (2006). Ibn Ashur Treatise on Maqasid al-Shari'ah. London, UK: Biddles Ltd.

Kamaluddin, A.K., Manan, N. and Suyurno, S.S. (2005). Islamic Entrepreneurship. Shah Alam: Pusat Penerbitan Universiti (UPENA).

Kayed, R.N. and Hassan, M.K. (2011). Islamic Entrepreneurship. New York: Routledge.

Kedah, Z., Adamu, I.M., Kadir, M.A.B.A. and Anwar, M.A. (2015). Effect of business Jihad on Entrepreneurs' ethical behavior and corporate social responsibility: A qualitative study. International Journal of Business and Globilisation, 15, 425-442.

Kuratko, D.F. (2016). Entrepreneurship: Theory, process, and practice. USA: Cengage Learning.

Low, M.B. and MacMillan, I.C. (1988). Entrepreneurship: Past research and future challenges. Journal of Management, 14(2), 139-161.

Lumpkin, G.T. and Dess, G.G. (1996). Clarifying the entrepreneurial orientation construct and linking it to performance. Academy of Management Review, 21 (1), 135-172.

Oukil, M.S. (2013). Entrepreneurship and entrepreneurs in an Islamic context. Journal of Islamic and Human Advanced Research, 3(3), 111-131.

Rindova, V., Barry, D. and Ketchen Jr, D.J. (2009). Entrepreneuring as emancipation. Academy of Management Review, 34(3), 477-491.

Sadeq, A. (1997). Entrepreneurship development and training: An Islamic perspective. Hamdard Islamicus, 20(4), 37-43. 
Schaper, M.T., Volery, T., Weber, P.C. and Gibson, B. (2011). Entrepreneurship and small business (3rd Asia-P). Milton: John Wiley and Sons Australia, Ltd.

Shane, S. and Venkataraman, S. (2000). The promise of entrepreneurship as a field of research. Academy of Management Review, 25(1), 217-226.

Solaiman, M. and Yasmin, S. (2012). Entrepreneurship development for rehabilitation of muslim youthinvestigating the role of Islamic Bank Bangladesh Ltd. (IBBL). Business Management Dynamics, 1(9), 13.

Soltanian, M., Zailani, S., Iranmanesh, M. and Aziz, A.A. (2016). Motivations of SME entrepreneurs to become Halalpreneurs. Journal of Science and Technology Policy Management, 7(2), 173-189.

Thomson Reuters. (2018). State of the Global Islamic Economy Report 2018/19. Retrieved from Haladinar website: https:/haladinar.io/hdn/doc/report2018.pdf 